\title{
MOTIVATION TYPES IN PREDICTING THE USE OF SECOND LANGUAGE LEARNING STRATEGIES BY ENGLISH MAJOR STUDENTS AT THE UNIVERSITY OF LANGUAGES AND INTERNATIONAL STUDIES - VIETNAM NATIONAL UNIVERSITY, HANOI
}

\author{
Bui Thien Sao*, Duong Thu Mai \\ VNU University of Languages and International Studies, Pham Van Dong, Cau Giay, Hanoi, Vietnam
}

Received 11 June 2018

Revised 26 September 2018; Accepted 27 September 2018

\begin{abstract}
This study examined the role of motivation types in predicting the use of language learning strategies by English major students at the University of Languages and International Studies - Vietnam National University, Hanoi (ULIS). A questionnaire was employed to collect information from 123 students. The first section of the questionnaire was about how often the students used strategies in learning English, and the second one collected information about the participants' levels of four motivation types. The results indicated that all the strategies were used by the majority of the respondents, and among four types of motivation, their instrumental motivation was of the highest level. Importantly, the study disclosed a significant and positive correlation between motivation and language learning strategy use. Finally, going beyond the correlational analysis already observed in many other studies, this study utilized regression analysis which then helped unveil significant contributions of integrative and intrinsic motivation to strategy use. Helpful implication can be drawn from this study.
\end{abstract}

Keywords: language learning strategies, motivation types, English major students, EFL learners, regression analysis

\section{Introduction}

The strategies and techniques that language learners exploit to acquire the language and solve challenges in their language learning have been a thriving area of research, especially in second language (L2). Since the works by Rubin and Stern in the late 1970s, there have been a plethora of studies revealing the benefits of language learning strategies (LLSs) to L2 learning.

* Corresponding author. Tel.: 84-968261056 Email: sao.buithien@gmail.com
Bialystok (1978, p.71) claimed that learning strategies were the "optimal means for exploiting available information to improve competence in a second language”. More than a decade later, Cohen (1990), O'Malley and Chamot (1990), and Oxford (1990) found that appropriate use of LLSs could help students gain learning autonomy, process information more effectively, and improve their performance.

Besides, the variables affecting LLS use were also taken into consideration by several scholars. Among many variables, motivation 
has emerged as one of the most powerful besides age, sex, aptitude, etc. (Khamkhien, 2010; Oxford, 1990; Taguchi, 2002). However, the number of studies particularly on the relationship between motivation and LLS use was modest, and most of them did not pay attention to motivation types. Additionally, only correlation relationship was discussed to some extent in literature in the field (Al-Qahtani, 2013; Khamkhien, 2010; Lau \& Chan, 2003; Liu et al., 2014; Mochizuki, 1999; Oxford \& Nyikos, 1989), and little was known about the predictive power of motivation in explaining LLS use of EFL learners. The same is true for the context in Vietnam and at the University of Languages and International Studies - Vietnam National University, Hanoi (ULIS).

Thus, this study was conducted with an objective of expanding understanding about this relationship, especially the role of motivation types in explaining and predicting LLS use by English major students at ULIS.

\section{Literature review}

\subsection{Language learning strategies}

Ellis (1994, p. 532-533) affirmed that "strategies refer to both general approaches and specific actions or techniques used to learn an L2", and strategy use can be either behavioral or mental, either visible or invisible, which was consistent with the ideas of O'Malley and Chamot (1990) and Oxford (1989, 2001). Concerning whether strategy use necessitates consciousness or not, Ellis (1994), Oxford (2001), and Grabe (2009) agreed that learners make use of learning strategies intentionally until they can implement them skillfully and automatically. Above all, there was a consensus among these researchers that strategies affect learning process directly and indirectly, exerting positive influence on students' task solving, language skill development, language proficiency, communicative competence, learning autonomy, self-confidence, and aiming at making the process of learning easier and more feasible (Al-Qahtani, 2013; Dreyer \& Oxford, 1996; Duong, 2005; Ellis, 1994; Matsumoto, Hiromori, \& Nakayama, 2013; Moya, 2014; Nisbet, Tindal, \& Arroyo, 2005; O’Malley \& Chamot, 1990; Oxford, 1990; Oxford, 2001; Oxford \& Scarcella, 1992).

One of the controversial issues in this field was the classification of LLSs. In 1971, Rubin began to provide an insight into strategies used by the 'good language learners' and came to the latest classification in 1987 with three main groups of strategies: 'learning strategies', 'communication strategies', and 'social strategies'. However, Ellis (1986) argued that successful use of communication strategies may not be indicative of 'good language learners' because it may prevent language learning, for example, being excel at guessing meaning may prevent the desire for learning. Another outstanding way of categorizing LLSs belonged to O'Malley and Chamot (1990) with three types, namely 'metacognitive strategies', 'cognitive strategies', and 'socioaffective strategies'. The addition of social type was supposed to acknowledge the prominent role of interactional strategies in language learning (Griffiths, 2004). Besides, some other researchers such as Bialystok (1978), Chesterfield and Chesterfield (1985), and Stern (1992) also proposed their own classifications of LLSs.

Basing on the works of predecessors, Oxford developed a taxonomy that included almost all the strategies discussed before in the fields. As a result, Oxford's (1990) classification is the most inclusive with two major groups of 'direct' and 'indirect' ones 
which comprised six subgroups inside. The first main category of direct strategies is made up of three smaller groups namely 'memory strategies', 'cognitive strategies', and 'compensation strategies'. Divided into 'creating mental linkages', 'applying images and sounds', 'reviewing well', and 'employing action', the first group helps learners to store new language information and retrieve it later. The second group entails conscious ways of handling the target language with four subgroups of 'practicing', 'receiving and sending messages', 'analyzing and reasoning', and 'creating structure for input and output'. Meanwhile, the third group involves 'guessing intelligently' and 'overcoming limitations in speaking and writing' enabling learners to communicate despite knowledge limits (Oxford, 1990). When it comes to the second major category (indirect strategies), there are three subgroups: 'metacognitive strategies', 'affective strategies', and 'social strategies'. By 'metacognitive strategies', Oxford (1990) meant the strategies of 'centering learning', 'arranging and planning learning', and 'evaluating learning', which facilitate students' control of their own learning and cognition. Differently, 'affective strategies' refer to controlling and regulating emotion, motivation and behaviors with the strategies of 'lowering anxiety', 'encouraging oneself' and 'taking emotional temperature' (Oxford, 1990). Lastly, according to Oxford (1990), students utilize 'social strategies' by 'asking question', 'cooperating with others', and 'empathizing with others', which helps improve their social interaction with people. Some experts such as Brown (2007) and Ellis (1994) agreed that this is a very comprehensive, detailed and systematic taxonomy of strategies, which was also the reason why Oxford's (1990) work was selected to be the theoretical framework for this study. Moreover, corresponding to the taxonomy is Oxford's (1989) Strategy Inventory of Language Learning (SILL) which is a questionnaire on how students use the LLSs in their language learning. The version for speakers of other languages learning English of the SILL (Oxford, 1989) has been widely employed by researchers, and it served as the instrument for data collection in this study as well.

Concerning previous studies, several have investigated the frequency of using LLS by L2 learners, but the findings were different across studies. For example, metacognitive and cognitive strategies were revealed to be the most frequently used in Al-Hebaishi (2012), Al-Qahtani (2013), and Chand (2014) while metacognitive and memory strategies were found in Hayati (2015) and compensation in Mochizuki (1999), Oxford and Ehrman (1995). Similarly, there have been a certain number of studies in Vietnam, such as Doan (2012), Le (2011), Nguyễn and Trịnh (2011), Nguyễn, Trịnh, and Huỳnh (2012) to name but a few. While these three papers all discovered the dominance of metacognitive strategies, they are not congruent regarding the findings on other strategies. For example, Doan (2012) and Nguyễn and Trịnh (2011) found cognitive to be a frequently-used strategy group, but Le (2011) and Nguyễn, Trịnh, and Huỳnh (2012) ranked cognitive among the least commonlyused ones. However, the inconclusive findings were understandable because the participant samples possessed different characteristics (study levels, learning settings, etc.), and learning strategies were likely to be affected by many factors, which would be discussed later in this paper.

\subsection{Motivation in language learning}

As one of the pioneering researchers in this field, Gardner (1985) proposed three 
components of motivation namely 'effort', 'desire', and 'attitudes' to learning activity, which respectively referred to time for language learning and the drive of the learner, the degree of the want to improve language proficiency, and, finally, emotional behaviors or reactions in learning. According to Ahåt (2013), Deci and Ryan (1985), Dörnyei and Skehan (2003), Gardner and Lambert (1972), Gardner and Masgoret (2003), Hashemian and Soureshijani (2011), Khodadady and Khajavy (2013), Wigfield (2000), and Yu (2013), motivation plays a prominent role in L2 learning and achievement: the motivated students could recognize their goals, exert more effort to handle the tasks, have more aspiration and less anxiety, enjoy learning activities, draw lessons from success and failure, exploit LLSs as an effective tool to reach the goals, and are likely to achieve higher proficiency than the unmotivated. In Vietnam, Hoang's (2011) research provided support for both integrative and instrumental.

Defining motivation types also garnered a lot of attention. Gardner (1983), Gardner and Lambert (1972) posited that there were two types of motivation in language learning: integrative versus instrumental motivation. The former refers to the reasons mainly related to the learners' identification with the society (Gardner, 1983) or their desires and willingness to explore more about the culture of the region using the target language, to connect more with the local community or to be a member of that society (Gardner and Lambert, 1972, SavilleTroike, 2006). A typical illustration is the act of learning French of many English-speaking Canadians (Ellis, 2003). In contrast, the latter is derived purely from practical reasons or non-interpersonal purposes such as admission requirements or job promotion (Gardner \& Lambert, 1972; Saville-Troike, 2006). While both motivation types were theorized to be essential, Csizer and Dörnyei (2005), $\mathrm{Yu}$ (2013) found integrative motivation the more powerful contributor to success in L2 learning. Nonetheless, Dörnyei (1990), Gupta and Woldemariam (2011), Lukmani (1972), Rehman et al. (2014), Warden and Lin (2000), $\mathrm{Yu}$ (2014) showed that in EFL contexts where learners have few opportunities to use the foreign language or interact with foreigners, instrumental motivation was more important and stronger.

Other researchers raised another wellknown categorization which differentiated intrinsic and extrinsic motivation. Whilst the former means "motivation to engage in an activity for its own sake”, the latter refers to "motivation to engage in an activity as a means to an end" (Pintrich \& Schunk, 2002, p. 245). Brown (2007) also agreed that a person whose behavior is determined by external forces is extrinsically motivated. Homework, grade, and teachers are some of the external factors pushing the learner to get engaged in learning (Brown, 2007). As Harmer (1991) argued, both integrative and instrumental motivations can be categorized as extrinsic motivation. In Deci and Ryan's opinion (1985), being extrinsically motivated could do some harm to learning. That is, it is likely that when the rewards or even the punishment disappear, so does motivation. Concerning intrinsic type, Lightbown and Spada (1999) agreed that it brings no harmful effects because the needs derive from inside. It was even considered the underlying factor in L2 learning success (Baleghizadeh \& Rahimi, 2011; Grabe, 2009; Guthrie \& Wigfield, 2000; Liu et al., 2014). Regarding some studies with Vietnamese students as samples, Nguyen (2013) showed evidence for the major role of extrinsic and instrumental type in students' motivation for learning English while Ngo, Spooner-Lane, and Mergler (2015) affirmed that those who 
are intrinsically motivated exert greater effort in learning English. More interestingly, Phan (2010) found that learners' motivation levels changed depending on situations, and intrinsic motivation was usually overpowered by other types of motivation.

Another type was discussed by Ellis (2003, p.75): 'resultative motivation'. All above sorts of motivation have been identified based on the assumption that motivation stimulates language learning and contributes to achievement; however, in many cases, motivation could result from learning (Ellis, 2003). This scholar reasoned that success and sense of achievement in language learning could sustain existing level of motivation or may enhance or, in some contexts, weaken motivation.

Besides, Ellis (2003) seems to imply that integrative, instrumental and resultative categories all belong to extrinsic motivation because in Ellis's classification there are four types: integrative, instrumental, resultative, and intrinsic categories. In this research, Ellis's (2003) system of motivation was applied due to its comprehensive coverage of all main motivation types discovered previously.

\subsection{Language learning strategies and motivation in language learning}

The factors affecting L2 learners' strategy use have been increasingly studied. Among many factors, motivation was found to be the most influential by Oxford and Nyikos (1989). The superiority of motivation over study experience, gender, study major, English proficiency, enjoyment, etc., in correlating with and affecting LLS choice and use was supported in Khamkhien (2010), Lau and Chan (2003), and Mochizuki (1999). Vietnamese context can be related most closely to Khamkhien's (2010) because this work took Vietnamese students (along with Thai students) as the sample. Besides, significant correlation between LLS use and motivation was also reported in Al-Qahtani (2013), Baleghizadeh and Rahimi (2011), Gupta and Woldemariam (2011), Liu et al. (2014), Matsumoto, Hiromori, and Nakayama (2013), and Xu (2011).

Moreover, the relationship between LLS use and motivation was found to be mediated by different strategies and motivation types. Schmidt and Watanabe (2001) indicated that cognitive and metacognitive were correlated most strongly with motivation. In Oxford and Nyikos (1989), the students' instrumental desire was not interrelated with communication strategies. However, the opposite was found in Ehrman (1990). In the meantime, Al-Qahtani (2013) suggested that both integrative and instrumental strategies significantly correlated with LLS use, but the former possessed the higher correlation. For intrinsic and extrinsic motivation, Vandergrift (2005), Baleghizadeh and Rahimi (2011) showed that both were significantly correlated with strategies, but the higher correlation was between strategies and intrinsic motivation. In Oxford and Ehrman (1995), however, LLS use was interrelated with only intrinsic motivation.

The above listed studies had some undeniable strengths. For example, Oxford and Nyikos (1989), Schmidt and Watanabe's (2001) recruited a huge number of participants (1200 and 2089 respectively), and in Oxford and Nyikos (1989) there was a large amount of evidence for the SILL's reliability and validity. However, there existed some gaps and limitations. In Gupta and Woldemariam (2011), Lau and Chan (2003), Matsumoto, Hiromori, and Nakayama (2013), Vandergrift (2005), the focal attention of their research was the strategies for only one in four main English skills. Similarly, Baleghizadeh and Rahimi's (2011) research was confined to 
only metacognitive strategies. For some other studies, the measurement of motivation was not well-developed. In Khamkhien (2010), Mochizuki (1999), Oxford and Nyikos (1989), the number of items pertaining to motivation was relatively small (thirteen, one, and six respectively). What is more, Khamkhien (2010), Oxford and Nyikos (1989) only employed the dichotomous questions in the motivation questionnaires, which might not reflect exactly the students' opinion and their level of motivation. Additionally, many of the studies merely scrutinized one or two types of motivation or did not clarify the motivation types investigated. Several did not report the results for each motivation types either. Besides, some scholars noted that motivation is not stable in many cases (Dörnyei\&Skehan, 2003) and often changes as a function of study results, social and classroom setting, beliefs, and feelings (Grabe, 2009; Mazumder, 2014; Waninge, Bot, \& Dörnyei, 2014; Xu \& Case, 2015). Aside from this, different motivation types could be beneficial in different contexts as argued by Brown (2007). Therefore, the results of previous investigations are not always applicable to a certain place of another context. On top of that, the majority of previous studies in the field solely conducted correlation analysis while further analysis is worth investigating too. Conspicuously, more research is needed, especially in L2 context where the shortage of research exactly addressing the relationship between LLS use and motivation types is undeniable.

In short, it appears that there exists a relationship between motivation and what LLSs the learners use and how often these strategies were utilized. Nevertheless, the effects of different strategy groups and motivation types on the relationship have not been clarified thoroughly enough. This, along with the room for improvement in previous research, became the rationale behind the present study.

\section{Research questions}

This study was conducted to, first, identify the range of learning strategies used by the English majors at ULIS, and, secondly, the popular motivation types among them. Finally, it aimed at disclosing the role of their motivation types in explaining and predicting their use of LLSs. Briefly, the study sought to answer three questions:

1. What is the range of language learning strategies used by the English major students at ULIS?

2. What are their dominant types of motivation for English language learning?

3. What is the power of motivation types in predicting EFL students' use of language learning strategies?

\section{Methodology}

\subsection{Participants}

123 third-year undergraduates majoring in English at ULIS were the sample in this study. A vast majority of the participants were at the age of 21, and their first language was Vietnamese. Although the number was set randomly and was not the total number of the English major students (which was about four times higher for third year students and much more greater for the whole university, at the time of the study), the sample was large enough for a high chance of receiving a good reliability index later on and large enough for the authors to make valid generalization.

\subsection{Instrument}

After the pilot and consultation, the questionnaire was finalized and delivered to 
the EFL students. Although the informants were Vietnamese, the fact that they all majored in English and the researchers would serve as the questionnaire administrators to assure the most detailed and supportive instruction and assistance caused researchers to decide English as the language of the questionnaire.

Basically, the questionnaire included two main sections: one pertained to the students' use of LLSs, and the other was about their motivation to learn English (See Apendix).

The first section of the questionnaire adopted fifty statements in the SILL by Oxford (1989). There were six parts A, B, C, D, E and $\mathrm{F}$ corresponding to Oxford's six types of LLSs: memory, cognitive, compensation, metacognitive, affective and social strategies respectively. Each group was composed of the statements mentioning strategies used by language learners. For this section, the participants were required to rate how true these statements were for themselves on the scale of five options from (1) never or almost never true of me to (5) always or almost true of me. Oxford (1989) also suggested the way to interpret the mean scores of the students' selfratings. If the means are equal 4.5 or above (out of 5), the strategies are always or almost always used; if from 3.5 to less than 4.5 , the strategies are usually used; if from 2.5 to less than 3.5 , the frequency is medium, and the strategies are sometimes used; if from 1.5 to less than 2.5, the strategies generally are not used; if the mean is less than 1.5, the strategies are never or almost never used. This scale was applied to the interpretation of the results in this study as well. Besides, the validity of Oxford's questionnaire has been proven to be high through many tests, researches, and reviews (Oxford \& Nyikos, 1989), and in this study, the Cronbach alpha was also high at .883 .

The second section of the questionnaire consisted of 19 statements as to the students' motivation types. They divided into four parts of integrative, instrumental, resultative, and intrinsic motivation. In the first two parts, the items were adapted from Gardner (1985) and Hernandez (2006). The four items in the integrative motivation part mentioned the reasons related to the language beauty, the English culture and the people especially those from English speaking regions. Conversely, the eight items of the instrumental motivation part were about practical reasons to learn English, for example, the helpfulness of English in traveling and working in oversea environment, in getting better jobs, qualifications and in schooling. Next, adjusted from the investigation of Madrid and Pérez (2001), three items of the third part were designed to obtain information about learners' resultative motivation. Particularly, these items helped to identify if the study results negatively or positively affect students' motivation and how strong the influences are. Finally, intrinsic type was discussed in the last part with three items asking about learners' love and enjoyment for learning English itself. These items were from Tsai and Chang's (2013) questionnaire.

Besides, this section of the questionnaire also applied the 5-point Likert ranging from (1) strongly disagree to (5) strongly agree. Moreover, the way to interpret the mean scores was made compatible with the system used for the frequency of LLS use presented above. That is, if the mean scores were equal $4.5 / 5$ or higher, the students' motivation was considered extremely high; if from 3.5 to less than 4.5, their motivation was high, if from 2.5 to less than 3.5 , it was at medium level; if from 1.5 to less than 2.5 , their motivation was low; if less than 1.5 , the students were not motivated at all, or extremely low. Concerning the reliability, the Cronbach alpha of the motivation section was high at .860 . 


\subsection{Procedures}

After piloting the questionnaire with eight university students and consulting with the research supervisor, the researcher finalized the questionnaire and administered it to the students. When the instrument was delivered, the respondents were helped to understand the topic and purpose of the questionnaire. The overall guide was given in Vietnamese orally so that the students could fully understand what exactly they had to do to complete the questionnaire. The respondents filled in the form under the researcher's observation and they were encouraged to ask questions and give suggestions. Finally, the uncompleted answers or those with seemingly random ticks were excluded, and only the completed questionnaires were collected and counted. These answers were then used for data analysis.

\section{Results}

\subsection{The range of language learning strategies} used by the English major students at ULIS

The means of students' self-rating frequency of using six categories of LLSs is given in Table 1. Based on Oxford's (1989) scale, the frequencies of using LLSs were at a medium level $(3.31 / 5)$, that is, the majority of the students did not usually practice LLSs. It can be seen that among six groups of LLSs, metacognitive and social ones were exploited most frequently by the subjects. Metacognitive type was the only LLS type that reached the mean score slightly above 3.5 (out of 5), which signifies that they were usually used by the students (Oxford, 1989). All LLS groups other than metacognitive had their mean frequency between 3 and 3.5, which means the students sometimes used these sorts of LLSs. Among them, memories strategies were the least frequently used.

Table 1. Mean scores of the students' selfratings on their use of LLSs $(\mathrm{N}=123)$

\begin{tabular}{|c|c|c|c|}
\hline Strategy categories & Mean & SD & Rank \\
\hline a. Memory & 3.059 & 1.026 & 6 \\
\hline b. Cognitive & 3.332 & 0.937 & 4 \\
\hline c. Compensation & 3.341 & 1.003 & 3 \\
\hline d. Metacognitive & 3.510 & 0.937 & 1 \\
\hline e. Affective & 3.194 & 1.131 & 5 \\
\hline f. Social & 3.428 & 0.948 & 2 \\
\hline Strategy use overall & 3.311 & 0.284 & \\
\hline
\end{tabular}

More specifically, the most and the least popular LLSs across all six groups are displayed in Figure 1. Out of fifty strategies, twelve strategies had the means over 3.5/5, which made them most frequently used strategies (11b - 50f in Figure 1). The values ranged from $3.53 / 5$ to $3.98 / 5$, determining that these were usually used strategies. Out of every ten students asked, from five to seven answered that they usually or always employ these strategies. Noticeably, one-third of these strategies belonged to the category of metacognitive type (type d), the most frequently used type.

At the other end of the spectrum are seven most rarely used strategies $(5 \mathrm{a}-43 \mathrm{e}$ in Figure 1 ), of which the means were from $2.73 / 5$ to $2.93 / 5$. That means these strategies were sometimes utilized by the students. Only less than $30 \%$ of respondents reported a regular use of these strategies. Moreover, it is noteworthy that nearly two thirds of them were memory strategies (type a), the most rarely used type. 


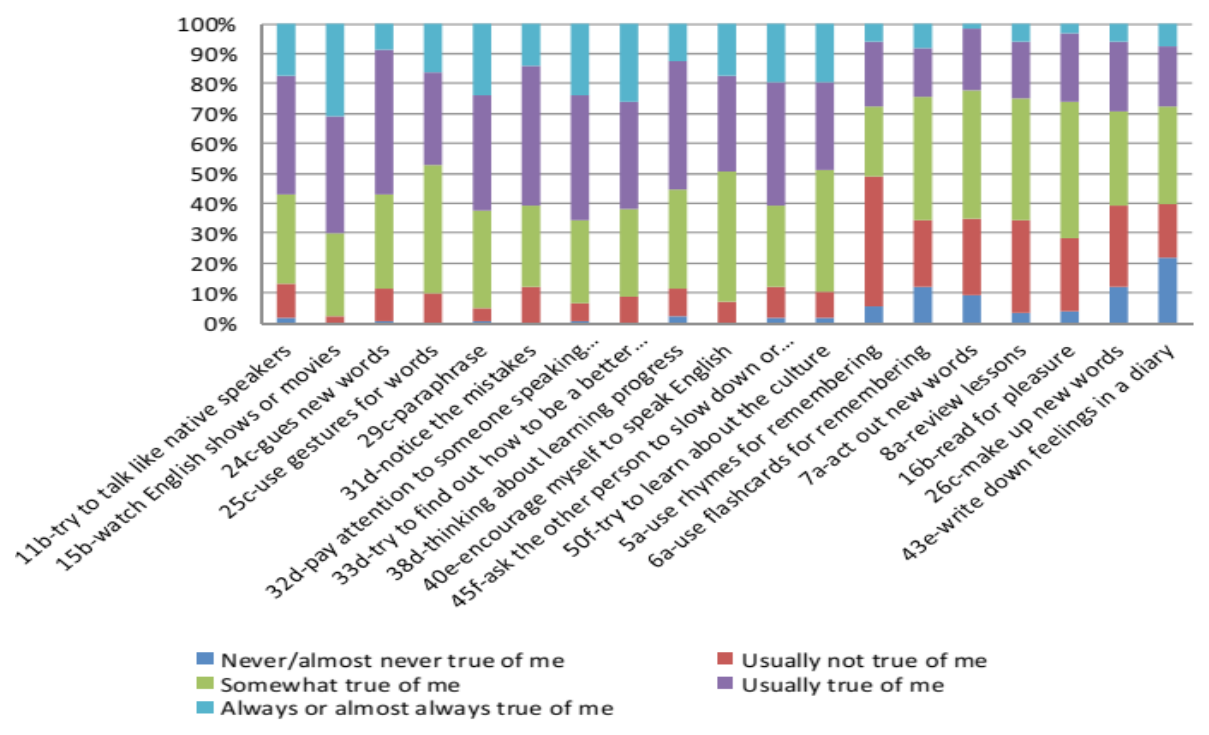

Figure 1. The students' frequency of using the most and the least popular strategies $(\mathrm{N}=123)$

\subsection{The students' types of motivation for English language learning}

Table 2 summarizes the mean scores of students' self-rated motivation levels for motivation in general and all four types in particular. Figure 2 presents in detail how the respondents rated their motivation. It can be seen that the average rate for motivation, in general, was at a high level (3.781/5). Moreover, ranging from just slightly under $3.5 / 5$ to roughly $4 / 5$, the means for all four motivation types were also high. This means the participants had strong motivation for learning English. 17 out of 19 given reasons for English learning were agreed by more than half of the participants. Among the four types, the second type or instrumental motivation was of the highest level and became the most dominant (3.961/5). This type had a huge $70 \%$ or above of the participants confirming agreement on nearly $80 \%$ of the listed reasons for learning English. It also possessed the most sizeable proportion of the respondents asserting their substantial motivation (eight out of nine statements got the strong agreement from more than $30 \%$ to nearly $45 \%$ participants). Figure 2 also indicated that six most motivating reasons belonged to this type (English was helpful for travel, career, business, further education, and development update).

Table 2. Mean scores of the students' self ratings on their motivation $(\mathrm{N}=123)$

\begin{tabular}{|c|c|c|c|}
\hline Motivation types & Mean & SD & Rank \\
\hline 1. Integrative & 3.730 & 0.971 & 2 \\
\hline 2. Instrumental & 3.961 & 0.977 & 1 \\
\hline 3. Resultative & 3.488 & 0.984 & 4 \\
\hline 4. Intrinsic & 3.607 & 0.995 & 3 \\
\hline Motivation overall & 3.782 & 0.266 & \\
\hline
\end{tabular}




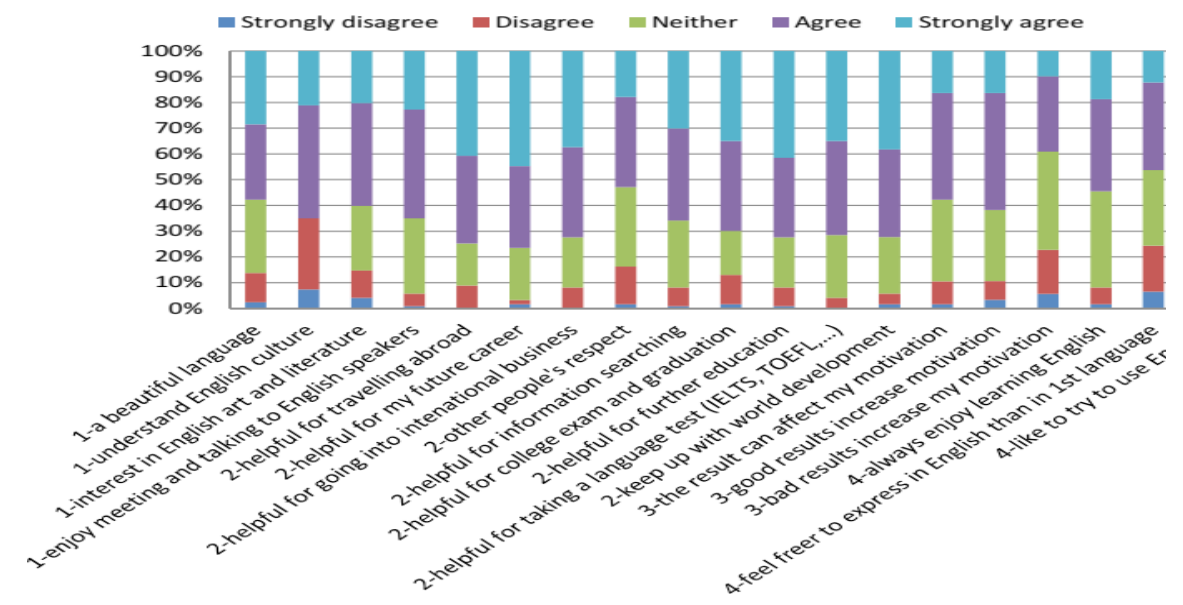

Figure 2. The students' motivation for learning English $(\mathrm{N}=123)$

Instrumental motivation type was followed by integrative, intrinsic, and resultative one. Only the resultative type was under 3.5 - the cut score for the high level of motivation; however, the gap was just negligible (3.487 vs. 3.5 ). The resultative type also had the statement that was least agreed as a motivator: Only less than $40 \%$ of students thought their motivation increased as a result of bad results or failures in English learning and using. Even though being the least motivating, the mean score for this statement still signified a medium level of motivation (3.2/5).

\subsection{The relationship between students' use of} LLSS and their motivation types

A Pearson product moment correlation was run to examine the correlations between variables (See Table 3). In general, the students' motivation significantly correlated with strategy use. The correlation was positive and at a moderate level $(\mathrm{r}=.341, \mathrm{p}<.001)$. This means the students who had a higher level of motivation for learning English tended to use strategies in learning English more frequently. However, this relationship was modified by the categories of LLSs and types of motivation. The students' general motivation was not interrelated with compensation and affective strategies but significantly correlated with the rest of strategies types, and the strongest correlation was with social strategies $(\mathrm{r}=$ $.349, \mathrm{p}<.001)$. For the overall strategy use, it correlated with all types of motivation except for the resultative one, and the strongest correlations were with intrinsic and integrative types $(r=.333$ and .331 respectively, $\mathrm{p}<.01)$.

Table 3. Correlations between the students' use of LLSs and their motivation $(\mathrm{N}=123)$

\begin{tabular}{|c|c|c|c|c|c|c|c|}
\hline & Strategy & Memory & Cognitive & Compensation & Metacognitive & Affective & Social \\
\hline Motivation & $.341^{* * *}$ & $.206^{*}$ & $.310^{* * *}$ & .173 & $.290^{* *}$ & .131 & $.349^{* * *}$ \\
\hline $\begin{array}{c}\text { Integrative } \\
\text { motivation }\end{array}$ & $.331^{* *}$ & .172 & $.312^{* * *}$ & $.211^{*}$ & $.282^{* *}$ & .099 & $.352^{* * *}$ \\
\hline $\begin{array}{c}\text { Instrumental } \\
\text { motivation }\end{array}$ & $.234^{* *}$ & .133 & $.217^{*}$ & .172 & $.209^{*}$ & .022 & $.256^{* *}$ \\
\hline $\begin{array}{c}\text { Resultative } \\
\text { motivation }\end{array}$ & .163 & $.208^{*}$ & .071 & -.046 & .147 & $.197^{*}$ & .110 \\
\hline $\begin{array}{c}\text { Intrinsic } \\
\text { motivation }\end{array}$ & $.333^{* *}$ & .156 & $.350^{* * *}$ & .092 & $.248^{* *}$ & $.224^{*}$ & $.334^{* * *}$ \\
\hline
\end{tabular}

$* \mathrm{p}<.05, * * \mathrm{p}<.01, * * * \mathrm{p}<.001$ 
Taking specific LLS groups and motivation types into consideration, it can be seen that cognitive, metacognitive, and social strategies were significantly correlated with integrative, instrumental, and intrinsic motivation while memory group only related significantly with resultative motivation. Differently, compensation category merely correlated significantly with integrative motivation, and affective strategies only correlated with resultative and intrinsic types. It is evident that memory and compensation groups had the tiniest number of significant correlations with four motivation types (only one). In the case of motivation types, it was resultative motivation which had only two significant correlations with strategy categories (with memory and affective strategies). By contrast, integrative and intrinsic motivation possessed the highest number of significant correlations with LLS use (4 out of 6). The instrumental one correlated significantly with three strategy groups (cognitive, metacognitive, and social).

In order to find out how strong different types of motivation could predict the students' LLS use, multiple regression analyses were conducted (See Table 4).

Table 4. Predictive power of the students' motivation types in explaining their LLS use $(\mathrm{N}=123)$

\begin{tabular}{|c|c|c|c|c|c|}
\hline Step & Predictors & $\mathrm{R}$ & $\mathrm{R}^{2}$ & $\Delta \mathrm{R}^{2}$ & $\Delta \mathrm{F}$ \\
\hline 1 & Intrinsic motivation & .333 & .111 & .111 & $15.114^{* * *}$ \\
\hline 2 & Integrative motivation & .378 & .143 & .032 & $4.452^{*}$ \\
\hline \multicolumn{6}{|c|}{ Excluded variables: resultative motivation, instrumental motivation } \\
\hline 1 & Integrative motivation & .331 & .110 & .110 & $14.908^{* * *}$ \\
\hline 2 & Intrinsic motivation & .378 & .143 & .033 & $4.641^{*}$ \\
\hline
\end{tabular}

In the first place, a stepwise regression analysis was run with all four types of motivation (See the top panel of Table 4). However, instrumental and resultative motivation were excluded from the model, leaving intrinsic and integrative motivation two significant predictors. Intrinsic type was placed at Step 1, significantly contributing $11.1 \%$ to the variance of strategy use $(\Delta \mathrm{F}=$ $15.114, \mathrm{p}<.001)$. Coming into the model at Step 2, integrative motivation also made a significant contribution, adding an additional $3.2 \%$ to the variance of LLS use $(\Delta \mathrm{F}=4.452$, $\mathrm{p}<.05$ ).

After that, to ensure the predictive power of intrinsic motivation in explaining LLS use, a hierarchical regression was implemented only with the two motivation types (intrinsic and integrative). The order was reverse to the first regression model (See the bottom panel of Table 4). In particular, entering at the first step, integrative motivation contributed significantly to the variance of LLS use $\left(\Delta \mathrm{R}^{2}=11 \%, \mathrm{p}<.001\right)$. Intrinsic motivation was entered at the second step after controlling for integrative motivation. The result showed that intrinsic motivation still significantly explained $3.3 \%$ of the variance of LLS use, remaining a significant predictor $(\Delta \mathrm{F}=4.641, \mathrm{p}<.05)$.

Overall, in four types of motivation, only integrative and intrinsic motivation were significant predictors of language learning strategy use. 


\section{Discussion}

This research was conducted to examine the relationship between LLS use and motivation of English major students at ULIS. Generally, these two variables correlated significantly with each other and two types of motivation, that is, integrative and intrinsic motivation were shown to be significant predictors of LLS use.

Addressed in the first research question, the students' English learning strategy use came to light. The finding was that, generally, the participants did not often make use of LLSs in learning English. The most frequently used strategies were metacognitive strategies, followed by social, compensation, cognitive, affective, and memory strategies. This finding was consistent to Al-Hebaishi (2012), AlQahtani (2013), Chand (2014), Doan (2012), Hayati (2015), Le (2011), Nguyễn and Trịnh (2011), Nguyễn, Trịnh, and Huỳnh (2012) in that metacognitive strategies were used the most often by the students. This indicates that students gave a higher priority to centering, arranging, planning and evaluating their own learning. They, to a lesser extent, paid attention to how to deal with their learning materials (cognitive strategies), benefit from socializing with others (social strategies), and make up for their knowledge limit by using strategies (compensation strategies). The most rarely practiced were controlling and sharing feeling strategies (affective strategies) and memory strategies. In the same fashion, Doan (2012) also proved that affective and memory strategies were utilized much less than other strategy groups. These above findings can be justified by the students' study level and their major. Tertiary education is normally accompanied by a higher level of self-study and learning autonomy, which can lead to the superiority of metacognitive strategy use over other strategies. Moreover, the participants also specialized in English, so, understandably, they did care about the progress and achievement in English skills - their major, and this is what metacognitive strategies deal with. Furthermore, their English possibly had reached the level that memorizing English vocabulary or structures ceased to be a burden or the main focus to them. As a result, memory strategies were the least frequently used.

The second question's concern was the students' dominant types of motivation. The results revealed that they were strongly motivated to learn English, and their motivation level of each type was high. This might be the result of the fact that the participants majored in English. It was likely that they had to think over to decide on what they would like to pursue before taking the university entrance exam, and the decision was often based on their desire, their strengths, and family's suggestions. Hence, to a certain extent, the students would have an internal interest in learning the language and the culture. Moreover, they were working with English in focus and probably preferred to make a living mainly by taking advantage of their English skills. Hence, the special significance of English in study, graduation, and future career made their instrumental motivation reach a high level. In this study, the students' instrumental motivation was stronger than their integrative motivation, which was consistent with the findings and conclusion by Al-Qahtani (2013), Dörnyei (1990), Gupta and Woldemariam (2011), Lukmani (1972), Rehman et al. (2014), Nguyen (2013), Warden and Lin (2000), and Yu (2014). Moreover, it was also the strongest type of motivation for the participants, followed by integrative, intrinsic, and resultative one. For the case of resultative type, the students' motivation level 
was at a medium level. However, it should not be interpreted that the respondents were not highly motivated by the results of their English learning because the score for resultative type was averaged out to some extent by the third statement referring to the influence of bad results and failure on their motivation. Instead, it should be understood that good results and success in learning English were much more encouraging for the majority of students than bad results and failures.

Finally, the third research question focused on the relationship between motivation and LLS use. It was found that the students' motivation correlated significantly, positively, and moderately with the frequency of using LLSs. This finding is completely in keeping with the studies by Al-Qahtani (2013), Baleghizadeh and Rahimi (2011), Gupta and Woldemariam (2011), Lau and Chan (2003), Liu et al. (2014), Khamkhien (2010), Matsumoto, Hiromori, and Nakayama (2013), Oxford and Nyikos (1989), Schmidt and Watanabe (2001), and $\mathrm{Xu}$ (2011) which claimed that as the level of students' motivation increases, the frequency of using LLSs tends to increase.

Among six groups of LLSs, cognitive, metacognitive, and social were interrelated most closely to motivation types, which might result from the higher frequency of using these categories of LLSs. This result is in line with Schmidt and Watanabe (2001). Concerning four motivation types, the integrative, instrumental, and intrinsic types were rated higher than resultative one, and they also correlated more strongly with LLS use than the resultative type. Intrinsic motivation was shown to possess the strongest relationship with strategy use, followed by integrative motivation. Obviously, this supports the findings by Vandergrift (2005), Baleghizadeh and Rahimi (2011), and Al-Qahtani (2013) which asserted that intrinsic motivation correlated more strongly with strategy use than extrinsic motivation, and integrative motivation correlated more strongly with strategy use than instrumental motivation.

Of great concern was the contribution of motivation types to the use of LLSs, which has not been investigated much in the field of L2 learning. Among these four types, only intrinsic and integrative motivation significantly contributed to LLS exploitation, becoming two significant predictors of strategy use. It is interesting to note that although instrumental motivation was the dominant motivation type for the EFL learners, it did not correlate with LLS use as strongly as intrinsic or integrative motivation and could not significantly explain or predict their use of LLS. Somehow, the findings were comparable with Al-Qahtani's (2013) which reported that the students were motivated more instrumentally than integratively, but it was integrative motivation that correlated more strongly with strategies. In the case of the current research, it is possible that the students' level of instrumental motivation was above the sufficient level for predicting LLS use, so it lost the power in predicting LLS use. For resultative type, the absence of its contribution to LLS use might be due to the fact that it was not rated as a strong motivation by the participants.

Obviously, it was shown in this study that the relationship between motivation and LLS use was not only mediated by motivation level but also motivation types, which lent support to the view that the relationship between EFL learners' motivation and LLS use was affected by many aspects of motivation other than motivation level (Al-Qahtani, 2013; Baleghizadeh \& Rahimi, 2011; Ehrman, 1990; Oxford \& Nyikos, 1989, 1995; Schmidt \& Watanabe, 2001; Vandergrift, 2005). 
Furthermore, the results also gave evidence for previous conclusions by Baleghizadeh and Rahimi (2011), Grabe (2009), Guthrie and Wigfield (2000), Liu et al. (2014) that intrinsic motivation plays a prominent role in language learning. Concerning the finding about integrative motivation, the present study also supported the argument that integrative motivation was a significant contributor to the students' success in L2 learning while instrumental type was not (Csizer \& Dörnyei, 2005; Yu, 2013).

Observably, the results of the current study were not congruent with some other studies such as Lukmani (1972) and Warden and Lin (2000) which favored instrumental motivation and gave no evidence for integrative motivation in L2 learning. However, it should be taken into consideration that these studies did not concentrate on the LLS use. In fact, there has been only a modest number of studies on this topic. More importantly, as mentioned before, it was conceded that motivation can change over time or vary as a result of changes in learning achievement, learning environment, learning contexts, beliefs and emotions (Brown, 2007; Dörnyei \& Skehan, 2003; Grabe, 2009; Mazumder, 2014; Waninge, Bot, \& Dörnyei, 2014; Xu\& Case, 2015). This, to some extent, can account for the variations and conflicts in findings across studies to date.

\section{Conclusion}

On the whole, this research investigated the relationship between the ULIS English major students' use of language learning strategies and their motivation types. First and foremost, it was found that all the LLSs were used by the majority of respondents, but they did not utilize them regularly in general. Among six groups, only metacognitive strategies were used on a regular basis. For all the other categories, the strategies were sometimes applied by the surveyed students. Relatively, metacognitive and social strategies were exploited the most frequently. In contrast, two classes of memory and affective were the least familiar strategies. Secondly, the students had strong motivation for learning English in terms of all the four types addressed, that is integrative, instrumental, resultative, and intrinsic motivation. Among the four, instrumental motivation was of the highest level. Lastly, the relationship between LLS use and motivation was enlightened. In general, these two variables significantly correlated with each other. Motivation types were presented to correlate most strongly with cognitive, metacognitive, and social strategies, and strategy use was interrelated significantly with all motivation types except the resultative one. Furthermore, LLS use was significantly explained and predicted only by intrinsic and integrative motivation.

Helpful implication can be drawn from this study. Firstly, using the SILL by Oxford (1989) and motivation questionnaires can be very helpful for language teachers to understand more comprehensively about their own students: what strategies they use, and what motivates them the most. The teachers, then, can help them by raising the students' awareness of learning how to learn the language, explicitly introducing LLSs in language sessions, or designing strategybased instruction. To motivate learners' motivation, the instructors should be flexible and opt for appropriate ways depending on situations. Besides reminding the students of the advantages of being proficient at English, or designing the tasks that could prove the usefulness of English skills, the instructors could also give the learners opportunities to expose to English culture (literature, movies, 
people,...), organize intriguing activities, give constructive and encouraging feedback to inspire their students, and even play a role model of a teacher who is intrinsically motivated to teach English.

However, the study still had some limitations. First of all, the instruments making use of self-report had certain inherent limitations, which, in fact, was common in the research of this field. Further study should recruit more participants to gather more reliable data, and the students of disciplines other than English should be of concern. Also, interview or think aloud method can be employed along with questionnaires to obtain more insightful results.

\section{References}

\section{Vietnamese}

Nguyễn Thành Đức \& Trịnh Hồng Tính (2011). Mức độ sử dụng các chiến lược đọc nhận thức và siêu nhận thức của sinh viên chuyên ngành Anh văn. Tạp chí Khoa hoc Trưòng Đại học Cần Tho, 19b, 104-109.

Nguyễn Thành Đức, Trịnh Hồng Tính, \& Huỳnh Minh Thư (2012). Các chiến lược học ngôn ngữ của sinh viên không chuyên Anh văn tại Trường Đại học Cần Thơ. Tạp chí Khoa học Truò̀ng Đại hoc Cần Tho, $22 b, 42-49$.

\section{English}

Ahåt, R. (2013). Motivation, gender, and learner performance of English as an L3 in the Xinjiang Uyghur autonomous region. English Language Teaching, 6(9), 158-167.

Al-Hebaishi, S. M. (2012). Investigating the relationship between learning styles, strategies and the academic performance of Saudi English majors. International Interdisciplinary Journal of Education, 1(8), 510520.

Al-Qahtani, M. F. (2013). Relationship between English language, learning strategies, attitudes, motivation, and students' academic achievement. Education in Medicine Journal, 5(3), 19-29.

Baleghizadeh, S., \& Rahimi, A. H. (2011). The relationship among listening performance, metacognitive strategy use and motivation from a self-determination theory perspective. Theory and Practice in Language Studies, 1(1), 61-67.
Bialystok, E. (1978). A theoretical model of second language learning. Language Learning, 28(1), 6983.

Brown, H. D. (2007). Principles of language learning and teaching. New York: Longman.

Chand, Z. A. (2014). Language learning strategy use and its impact on proficiency in academic writing of tertiary students. Procedia - Social and Behavioral Sciences, 118, 511-521.

Chesterfield, R., \& Chesterfield, K. (1985). Natural order in children's use of second language learning strategies. Applied Linguistics, 6(1), 45-59.

Cohen, A. D. (1990). Language learning: Insights for learners, teachers and researchers. New York: Newbury House.

Csizér, K., \& Dörnyei, Z. (2005). The internal structure of language learning motivation and its relationship with language choice and learning effort. The Modern Language Journal, 89(1), 19-36.

Deci, E. L., \& Ryan, R. M. (1985). Intrinsic Motivation and Self-determination in Human Behavior. New York: Plenum.

Doan, T. T. P. (2012). The relationship between language learning strategies and English proficiency of 4th year students at FELTE, ULIS, VNU. Unpublished master thesis, University of Languages and International Studies, Hanoi, Vietnam.

Dörnyei, Z. (1990). Conceptualizing motivation in foreign language learning. Language Learning, 40(1), 45-78.

Dörnyei, Z., \& Skehan, P. (2003). Individual differences in second language learning. In C. Doughty \& M. Long (Eds.), Handbook of second language acquisition. Oxford: Backwell.

Dreyer, C., \& Oxford, R. L. (1996). Prediction of ESL proficiency among African speakers in South Africa. In R. L. Oxford (Ed.), Language learning strategies around the world: Crosscultural perspective (pp. 61-74). Manoa: University of Hawaii Press.

Duong, T. M. (2005). An experimental on the application of strategy-based instructions to the teaching writing skills to first-year students at College of Foreign Languages, Vietnam National University. Unpublished master thesis, University of Languages and International Studies, Hanoi, Vietnam.

Ehrman, M. (1990). The role of personality type in adult language learning: An ongoing investigation. In T. Parry, \& C. Stansfield (Eds.), Language Aptitude Reconsidered (pp.126-178). Englewood Cliffs, N.J.: Prentice-Hall.

Ellis, R. (1986). Understanding second language acquisition. Oxford: Oxford University Press.

Ellis, R. (1994). The study of second language acquisition. Oxford: Oxford University Press. 
Ellis, R. (2003). Second language acquisition (9th ed.). Oxford: Oxford University Press.

Gardner, R. C. (1983). Learning another language: a true social psychological experiment. Journal of Language and Social Psychology, 2, 219-240.

Gardner, R. C. (1985). Social psychology and second language learning: The role of attitudes and motivation. London: Edward Arnold Publishers.

Gardner, R. C., \& Masgoret, A. M. (2003). Attitudes, motivation, and second language learning: A metaanalysis of studies conducted by Gardner and Associates. Language Learning, 53(1), 123-163.

Gardner, R., \& Lambert, W. (1972). Attitudes and motivation in second language learning. Rowley, MA: Newbury House.

Grabe, W. (2009). Reading in a second language: Moving from theory to Practice. Cambridge: Cambridge University Press.

Griffiths, C. (2004). Language learning strategies: Theory and research. Occasional Paper No. 1. Auckland: School of Foundation Studies, AIS St Helens. Retrieved September 15, 2017, from http:// crie.org.nz/research-papers/c_griffiths_op1.pdf

Gupta, D., \& Woldemariam, G. S. (2011). The influence of motivation and attitude on writing strategy use of undergraduate EFL students: Quantitative and qualitative perspectives. The Asian EFL Journal Quarterly, 13(2), 34-89.

Guthrie, J. \& Wigfield, A. (2000). Engagement and motivation in reading. In M. Kamil, P. Mosenthal, P. D. Pearson \& R. Barr (Eds.), Handbook of reading research (Vol. 3, pp. 403-422). Mahwah, NJ: Lawrence Erlbaum.

Harmer, J. (1991). The practice of English language teaching. London: Longman.

Hashemian, M., \& Soureshijani, H. (2011). The interrelationship of autonomy, motivation, and academic performance of Persian L2 learners in distance education contexts. Theory and practice in Language Studies, 1(4), 319-326.

Hayati, N. (2015). A study of English language learning beliefs, strategies, and English academic achievement of the ESP students of Stienas Samarinda. Dinamika Ilmu, 15(2), 297-323.

Hernandez, T. (2006). Integrative motivation as a predictor of success in the intermediate foreign language classroom. Foreign Language Annals, 39, 605-617.

Hoang, D. D. (2011). Motivation in the development of English speaking skills by second year tourism major students at Sao Do University. VNU Journal of Foreign Languages 27(3), 205-215.

Khamkhien, A. (2010). Factors affecting language learning strategy reported usage by Thai and
Vietnamese EFL learners. Electronic Journal of Foreign Language Teaching, 7(1), 66-85.

Khodadady, E., \& Khajavy, G. H. (2013). Exploring the role of anxiety and motivation in foreign language achievement: A structural equation modeling approach. Porta Linguarum, 20(6), 269-286.

Lau, K. L., \& Chan, D. (2003). Reading strategy use and motivation among Chinese good and poor readers in Hong Kong. Journal of Research in Reading, 26(2), 177-190.

Le, Q. D. (2011). An investigation into language learning strategies used by ethnic non-English major students at a university in the north of Vietnam. Unpublished doctoral dissertation, University of Languages and International Studies, Hanoi, Vietnam.

Lightbown, P. M., \& Spada, N. (1999). How languages are learned. Oxford: Oxford University.

Liu, W. C., Wang, C. K. J., Kee, Y. H., Koh, C., Lim, B. S. C., \& Chua, L. (2014). College students' motivation and learning strategies profiles and academic achievement: a self-determination theory approach. Educational Psychology, 34(3), 338-353.

Lukmani, Y. (1972). Motivation to learn and language proficiency. Language Learning, 22(2), 261-274.

Madrid, D., \& Pérez, M. L. (2001). Exploring the student's motivation in the EFL class. In E. García Sánchez (Ed.), Present and future trends in TEFL (pp. 321-364). University of Almería, Spain: Secretariado de Publicaciones.

Matsumoto, H., Hiromori, T., \& Nakayama, A. (2013). Toward a tripartite model of $\mathrm{L} 2$ reading strategy use, motivations, and learner beliefs. System, 41(1), 3849.

Mazumder, Q. (2014). Student motivation and learning strategies of students from USA, China and Bangladesh. International Journal of Evaluation and Research in Education, 3(4), 205-210.

Mochizuki, A. (1999). Language learning strategies used by Japanese university students. RELC Journal, 30(2), 101- 113 .

Moya, M. (2014). Developing a strategy-based instruction approach to teaching and learning modern languages to train ab-initio primary PGCE trainees. Journal of Pedagogic Development, 4I(1), 3-11.

Nisbet, D., Tindal, E., \& Arroyo, A. (2005). Language learning strategies and English proficiency of Chinese university students. Foreign Language Annals, 38(1), 100-107.

Ngo, H., Spooner-Lane, R., \& Mergler, A. (2015). A comparison of motivation to learn English between English major and non-English major students in a Vietnamese university. Innovation in Language Learning and Teaching, 11(2), 188-202. 
Nguyen, T. T. (2013). A study on 10 graders'motivation in Speaking activities at Son Tay high school, Ha Noi. Unpublished master thesis, University of Languages and International Studies, Hanoi, Vietnam.

O’Malley, J. M., \& Chamot, A. U. (1990). Learning strategies in second language acquisition. Cambridge: Cambridge University Press.

Oxford, R. L. (1989). Use of language learning strategies: A synthesis of studies with implications for strategy training. System, 17(2), 235-247.

Oxford, R. L. (1990). Language learning strategies: What every teacher should know? Boston: Heinle \& Heinle.

Oxford, R. L. (2001). Language learning styles and strategies. In M. Celce-Murcia (Ed.), Teaching English as a second or foreign language (pp. 359366). Boston: Heinle \& Heinle.

Oxford, R. L., \& Scarcella, R. (1992). The tapestry of language learning. Boston: Heinle \& Heinle.

Oxford, R., \& Ehrman, M. (1995). Adults' language learning strategies in an intensive foreign language program in the Untied States. System, 23(3), 359386.

Oxford, R., \& Nyikos, M. (1989). Variables affecting choice of language learning strategies by university students. The Modern Language Journal, 73(3), 291-300.

Phan, T. T. H. (2010). Factors affecting the motivation of Vietnamese technical English majors in their English studies. Unpublished doctoral dissertation, University of Otago, Otago, New Zealand.

Pintrich, P. R., \& Schunk, D. H. (2002). Motivation in education: Theory, research, and applications (2nd ed.). Upper Saddle River, NJ: Prentice Hall.

Rehman, A., Bilal, H. A., Sheikh, A., Bibi, N., \& Nawaz, A. (2014). The role of motivation in learning English language for Pakistani learners. International Journal of Humanities and Social Science, 4(1), 254-258.

Saville-Troike, M. (2006). Introducing second language acquisition. New York: Cambridge University Press.

Schmidt, R., \& Watanabe, Y. (2001). Motivation, strategy use, and pedagogical preferences in foreign language learning. In Z. Dörnyei \& R. Schmidt (Eds.), Motivation and second language acquisition (pp. 313-359). Honolulu: University of Hawaii.
Stern, H. H. (1992). Issues and options in language teaching. Oxford: Oxford University Press.

Taguchi, T. (2002). Learner factors affecting the use of learning strategies in cross-cultural contexts. Prospect, 17(2), 18-34.

Tsai, C. C., \& Chang, I. C. (2013). The study on motivation and anxiety of English learning of students at a Taiwan technical university. International Journal of English Language Teaching, 1(1), 24-41.

Vandergrift, L. (2005). Second language listening: Listening ability or language proficiency? The Modern Language Journal, 90(1), 6-18.

Waninge, F., Bot, K. D., \& Dörnyei, Z. (2014). Motivational dynamics in language learning: Change, stability, and context. The Modern Language Journal, 98(3), 704-723.

Warden, C., \& Lin, H. (2000). Existence of integrative motivation in an Asian EFL setting. Foreign Language Annals, 33(5), 535-547.

Wigfield, A. (2000). Facilitating children's reading motivation. In L. Baker, M. Dreher, \& J. Guthrie (Eds.), Engaging young readers: Promoting achievement and motivation (pp. 140-158). New York: Guilford Press.

Xu, W., \& Case, R. E. (2015). Age-related differences in motivation in learning English among Mainland Chinese students. International Journal of Applied Linguistics, 25(1), 67-82.

$\mathrm{Xu}, \mathrm{X}$. (2011). The relationship between language learning motivation and the choice of language learning strategies among Chinese graduates. International Journal of English Linguistics, 1(2), 203-212.

Yu, B. -H. (2013). Asian international students at an Australian university: Mapping the paths between integrative motivation, competence in L2 communication, cross-cultural adaptation and persistence with structural equation modeling. Journal of Multilingual and Multicultural Development, 34(7), 727-742.

Yu, X. -M. (2014). A comparative study on learning motivation of college students of different levels. English Language and Literature Studies, 4(2), 22-29. 


\title{
ĐộNG LỰC HỌC TRONG DỰ ĐOÁN VIỆC SỬ DỤNG CHIẾN LƯỢC HỌC NGOẠI NGỮ CỦA SINH VIÊN CHUYÊN NGÀNH TIẾNG ANH TẠI TRƯỜNG ĐẠI HỌC NGOẠI NGỮ - ĐẠI HỌC QUỐC GIA HÀ NỘI
}

\author{
Bùi Thiện Sao, Dương Thu Mai \\ Trương Đại học Ngoại ngũu, ĐHQGHN, Phạm Văn Đồng, Cầu Giấy, Hà Nội, Việt Nam
}

Tóm tắt: Bài nghiên cứu tập trung tìm hiểu vai trò các loại động lực học tập trong dự đoán việc sử dụng chiến lược học ngoại ngữ của sinh viên chuyên ngành tiếng Anh tại Trường Đại học Ngoại ngữ - Đại học Quốc gia Hà Nội (ULIS). Phiếu hỏi đã được sử dụng để thu thập thông tin từ 123 sinh viên. Phần thứ nhất của mẫu hỏi nhằm xác định tần suất sinh viên sử dụng chiến lược học trong việc học tiếng Anh và phần thứ hai thu thập thông tin về mức độ các loại động lực học tập của sinh viên. Kết quả chỉ ra rằng tất cả các chiến lược đã được sử dụng bởi phần lớn những sinh viên tham gia nghiên cứu, và trong số bốn loại động lực học, loại động lực mang tính phương tiện (instrumental motivation) có mức độ cao nhất. Quan trọng hơn, nghiên cứu cũng chỉ ra mối tương quan thuận rõ ràng giữa động lực học và việc sử dụng chiến lược học ngôn ngữ. Cuối cùng, tiến xa hơn các nghiên cứu tương quan, nghiên cứu này tiếp tục áp dụng phân tích hồi quy để tìm ra sự đóng góp rõ ràng của động lực hòa nhập cộng đồng (integrative motivation) và động lực nội sinh (intrinsic motivation) trong dự đoán, giải thích việc sử dụng các chiến lược học. Một số ý nghĩa sư phạm cũng được rút ra từ kết quả nghiên cứu.

Tù khóa: chiến lược học ngoại ngữ, động lực học ngoại ngữ, sinh viên chuyên ngành tiếng Anh, người học ngoại ngữ, phân tích hồi quy dự đoán

\section{APPENDIX}

\section{QUESTIONNAIRE}

SECTION 1: Strategy Inventory for Language Learning (Version 7.0 (ESL/EFL) (C)R.L.Oxford, 1989)

Please put a tick on the appropriate number that tells HOW TRUE OF YOU THE STATEMENT IS.

\begin{tabular}{|c|c|c|c|c|}
\hline $\mathbf{1}$ & $\mathbf{2}$ & $\mathbf{3}$ & $\mathbf{4}$ & $\mathbf{5}$ \\
\hline $\begin{array}{c}\text { Never or almost } \\
\text { never true of me }\end{array}$ & $\begin{array}{c}\text { Usually not } \\
\text { true of me }\end{array}$ & $\begin{array}{c}\text { Somewhat true } \\
\text { of me. }\end{array}$ & $\begin{array}{c}\text { Usually true } \\
\text { of me. }\end{array}$ & $\begin{array}{c}\text { Always or almost } \\
\text { always true of me }\end{array}$ \\
\hline
\end{tabular}

\begin{tabular}{|l|l|l|l|l|l|c|}
\hline \multicolumn{9}{|c|}{ PART A: Memory strategies } \\
\hline 1 & I think of relationships between what I already know and new things I learn in English. & 1 & 2 & 3 & 4 & 5 \\
\hline
\end{tabular}




\begin{tabular}{|c|c|c|c|c|c|c|}
\hline 2 & I use new English words in a sentence so I can remember them. & 1 & 2 & 3 & 4 & 5 \\
\hline 3 & $\begin{array}{l}\text { I connect the sound of a new English word and an image or picture of the word to help } \\
\text { me remember the word. }\end{array}$ & 1 & 2 & 3 & 4 & 5 \\
\hline 4 & $\begin{array}{l}\text { I remember a new English word by making a mental picture of a situation in which } \\
\text { the word might be used. }\end{array}$ & 1 & 2 & 3 & 4 & 5 \\
\hline 5 & I use rhymes to remember new English words. & 1 & 2 & 3 & 4 & 5 \\
\hline 6 & I use flashcards to remember new English words. & 1 & 2 & 3 & 4 & 5 \\
\hline 7 & I physically act out new English words. & 1 & 2 & 3 & 4 & 5 \\
\hline 8 & I review English lessons often. & 1 & 2 & 3 & 4 & 5 \\
\hline 9 & $\begin{array}{l}\text { I remember new English words or phrases by remembering their location on the page, } \\
\text { on the board, or on a street sign. }\end{array}$ & 1 & 2 & 3 & 4 & 5 \\
\hline \multicolumn{7}{|c|}{ Part B: Cognitive strategies } \\
\hline 10 & I say or write new English words several times. & 1 & 2 & 3 & 4 & 5 \\
\hline 11 & I try to talk like native English speakers. & 1 & 2 & 3 & 4 & 5 \\
\hline 12 & I practice the sounds of English. & 1 & 2 & 3 & 4 & 5 \\
\hline 13 & I use the English words I know in different ways. & 1 & 2 & 3 & 4 & 5 \\
\hline 14 & I start conversations in English. & 1 & 2 & 3 & 4 & 5 \\
\hline 15 & I watch English language TV shows or go to movies spoken in English. & 1 & 2 & 3 & 4 & 5 \\
\hline 16 & I read for pleasure in English. & 1 & 2 & 3 & 4 & 5 \\
\hline 17 & I write notes, messages, letters, or reports in English. & 1 & 2 & 3 & 4 & 5 \\
\hline 18 & I first skim an English passage (read it quickly) then go back and read carefully. & 1 & 2 & 3 & 4 & 5 \\
\hline 19 & I look for words in my own language that are similar to new words in English. & 1 & 2 & 3 & 4 & 5 \\
\hline 20 & I try to find patterns in English. & 1 & 2 & 3 & 4 & 5 \\
\hline 21 & I find the meaning of an English word by dividing it into parts that I understand. & 1 & 2 & 3 & 4 & 5 \\
\hline 22 & I try not to translate word-for-word. & 1 & 2 & 3 & 4 & 5 \\
\hline 23 & I make summaries of information that I hear or read in English. & 1 & 2 & 3 & 4 & 5 \\
\hline \multicolumn{7}{|c|}{ Part C: Compensation strategies } \\
\hline 24 & To understand unfamiliar English words, I make guesses. & 1 & 2 & 3 & 4 & 5 \\
\hline 25 & When I can't think of a word during a conversation in English, I use gestures. & 1 & 2 & 3 & 4 & 5 \\
\hline 26 & I make up new words if I do not know the right ones in English. & 1 & 2 & 3 & 4 & 5 \\
\hline 27 & I read English without looking up every new word. & 1 & 2 & 3 & 4 & 5 \\
\hline 28 & I try to guess what the other person will say next in English. & 1 & 2 & 3 & 4 & 5 \\
\hline 29 & If I can't think of an English word, I use words or phrases that mean the same thing. & 1 & 2 & 3 & 4 & 5 \\
\hline \multicolumn{7}{|c|}{ Part D: Metacognitive strategies } \\
\hline 30 & I try to find as many ways as I can to use my English. & 1 & 2 & 3 & 4 & 5 \\
\hline 31 & I notice my English mistakes and use that information to help me do better. & 1 & 2 & 3 & 4 & 5 \\
\hline 32 & I pay attention when someone is speaking English. & 1 & 2 & 3 & 4 & 5 \\
\hline 33 & I try to find out how to be a better learner of English. & 1 & 2 & 3 & 4 & 5 \\
\hline 34 & I plan my schedule so I will have enough time to study English. & 1 & 2 & 3 & 4 & 5 \\
\hline
\end{tabular}




\begin{tabular}{|c|c|c|c|c|c|c|}
\hline 35 & I look for people I can talk to in English. & 1 & 2 & 3 & 4 & 5 \\
\hline 36 & I look for opportunities to read as much as possible in English. & 1 & 2 & 3 & 4 & 5 \\
\hline 37 & I have clear goals for improving my English skills. & 1 & 2 & 3 & 4 & 5 \\
\hline 38 & I think about my progress in learning English. & 1 & 2 & 3 & 4 & 5 \\
\hline \multicolumn{7}{|c|}{ Part E: Affective strategies } \\
\hline 39 & I try to relax whenever I feel afraid of using English. & 1 & 2 & 3 & 4 & 5 \\
\hline 40 & I encourage myself to speak English even when I am afraid of making a mistake. & 1 & 2 & 3 & 4 & 5 \\
\hline 41 & I give myself a reward or treat when I do well in English. & 1 & 2 & 3 & 4 & 5 \\
\hline 42 & I notice if I am tense or nervous when I am studying or using English. & 1 & 2 & 3 & 4 & 5 \\
\hline 43 & I write down my feelings in a language learning diary. & 1 & 2 & 3 & 4 & 5 \\
\hline 44 & I talk to someone else about how I feel when I am learning English. & 1 & 2 & 3 & 4 & 5 \\
\hline \multicolumn{7}{|c|}{ Part F: Social strategies } \\
\hline 45 & $\begin{array}{l}\text { If I do not understand something in English, I ask the other person to slow down or } \\
\text { to say it again. }\end{array}$ & 1 & 2 & 3 & 4 & 5 \\
\hline 46 & I ask English speakers to correct me when I talk. & 1 & 2 & 3 & 4 & 5 \\
\hline 47 & I practice English with other students. & 1 & 2 & 3 & 4 & 5 \\
\hline 48 & I ask for help from English speakers. & 1 & 2 & 3 & 4 & 5 \\
\hline 49 & I ask questions in English. & 1 & 2 & 3 & 4 & 5 \\
\hline 50 & I try to learn about the culture of English speakers. & 1 & 2 & 3 & 4 & 5 \\
\hline
\end{tabular}

\section{SECTION 2: Motivation for language learning}

Please answers the following questions by putting a tick on appropriate number:

\begin{tabular}{|c|c|c|c|c|}
\hline 1 & $\mathbf{2}$ & $\mathbf{3}$ & $\mathbf{4}$ & $\mathbf{5}$ \\
\hline Strongly Disagree & Disagree & Neither & Agree & Strongly Agree \\
\hline
\end{tabular}

\begin{tabular}{|c|c|c|c|c|c|c|}
\hline \multicolumn{7}{|c|}{ PART 1: Integrative motivation: I learn English because... } \\
\hline 1 & I love the language as it is such a beautiful language. & 1 & 2 & 3 & 4 & 5 \\
\hline 2 & It will enable me to understand and appreciate more the English life style and culture. & 1 & 2 & 3 & 4 & 5 \\
\hline 3 & I am interested in English art and literature (music, movies, stories, articles, ...). & 1 & 2 & 3 & 4 & 5 \\
\hline 4 & $\begin{array}{l}\text { I enjoy meeting and having conversations with friends or people who speak } \\
\text { English, especially those from English speaking countries. }\end{array}$ & 1 & 2 & 3 & 4 & 5 \\
\hline \multicolumn{7}{|c|}{ PART 2: Instrumental motivation: I learn English because... } \\
\hline 1 & English will help me if I should ever travel abroad. & 1 & 2 & 3 & 4 & 5 \\
\hline 2 & English will be helpful for my (future) career (get good job or promotion). & 1 & 2 & 3 & 4 & 5 \\
\hline 3 & It will enable me to involve or go into an international business. & 1 & 2 & 3 & 4 & 5 \\
\hline 4 & Other people will respect me more if I know English. & 1 & 2 & 3 & 4 & 5 \\
\hline
\end{tabular}




\begin{tabular}{|c|c|c|c|c|c|c|}
\hline 5 & $\begin{array}{l}\text { I will be able to search for information and materials in English for my } \\
\text { assignments. }\end{array}$ & 1 & 2 & 3 & 4 & 5 \\
\hline 6 & English will help me to pass my exams and graduate from the college. & 1 & 2 & 3 & 4 & 5 \\
\hline 7 & It will enable me to further my education. & 1 & 2 & 3 & 4 & 5 \\
\hline 8 & $\begin{array}{l}\text { I need the language in order to take a test in future. (IELTS, TOEFL, TOIEC, } \\
\text {..). }\end{array}$ & 1 & 2 & 3 & 4 & 5 \\
\hline 9 & $\begin{array}{l}\text { It will enable me to keep up with development of world economy, science and } \\
\text { technology (globalization) }\end{array}$ & 1 & 2 & 3 & 4 & 5 \\
\hline \multicolumn{7}{|c|}{ PART 3: Resultative motivation } \\
\hline 1 & $\begin{array}{l}\text { My results or achievement in English learning increase or decrease my } \\
\text { motivation. }\end{array}$ & 1 & 2 & 3 & 4 & 5 \\
\hline 2 & $\begin{array}{l}\text { My motivation increases as a result of GOOD results, SUCCESSES, the } \\
\text { prizes, praise in English learning and using. }\end{array}$ & 1 & 2 & 3 & 4 & 5 \\
\hline 3 & $\begin{array}{l}\text { My motivation increases as a result of BAD results or FAILURES in English } \\
\text { learning and using. }\end{array}$ & 1 & 2 & 3 & 4 & 5 \\
\hline \multicolumn{7}{|c|}{ PART 4: Intrinsic motivation } \\
\hline 1 & I always enjoy learning English. & 1 & 2 & 3 & 4 & 5 \\
\hline 2 & I feel freer to express myself in English than I do in first language. & 1 & 2 & 3 & 4 & 5 \\
\hline 3 & I would like to try to use the English. & 1 & 2 & 3 & 4 & 5 \\
\hline
\end{tabular}

\section{General information}

Name:

Class:

Age: 